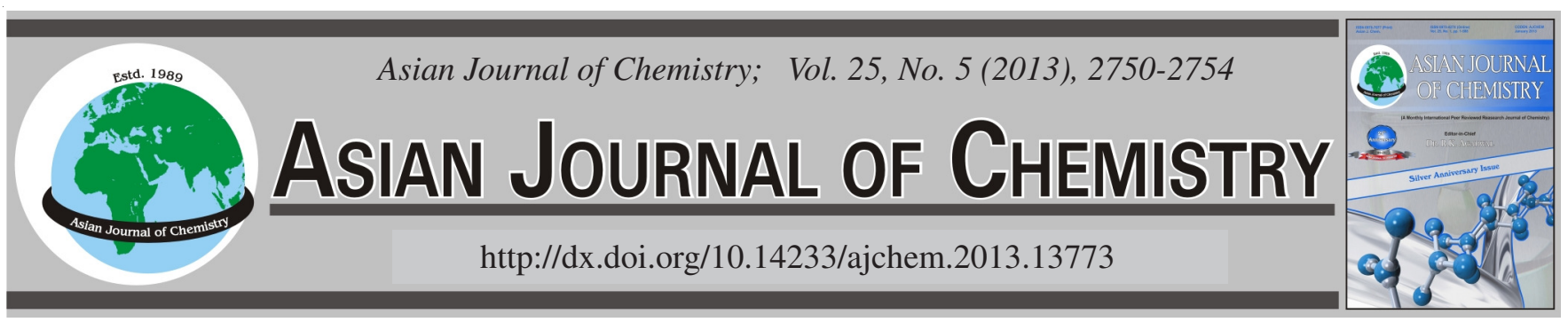

\title{
HPLC Analysis of Fatty Acids and Triterpenoids in Fruit of Hawthorn (Crataegus azarolus) in Iraqi Kurdistan Region
}

\author{
Baram Ahamd Ameen*, Srwa N. Majeed and Dalia A. Abdul
}

Department of Chemistry, School of Science, Faculty of Science \& Science Education, University of Sulaimani, P.O. Box: 334, Sulaimani, Iraq *Corresponding authors: E-mail: barmjaff@yahoo.com; dalyadya@yahoo.com

\begin{abstract}
Fatty acids and triterpenoids content of three types of hawthorn fruit (Crataegus azarolus) which grows in Iraqi Kurdistan region (season 2011) including Hawraman, Qaradax and house garden, were determined by RP-HPLC technique. The percentages of oils were found to be 12,10 and $14 \%$, respectively. HPLC analysis of these oils show contain palmatic acid, palmitoleic $(\omega 7)$ acid and high levels of $\alpha$ linoleic acid about [37.202, 31.402 and $33.816 \%$ ], linoleic acid [9.686, 21.556 and $19.135 \%$ ], respectively. Divert compounds of triterpenoids composition were also analyzed by HPLC technique in all of them mentioned four triterpenoids compound were detected oleanolic acid, ursolic acid, $\alpha$-amyrin, $\beta$-amyrin and a high ratio (choline, acetylcholine) have also been detected. The ratio of acetylcholine is about 53.800, 24.6144 and $30.8198 \%$ in each types, respectively and a high level of choline detected in Qaradax hawthorn fruits is about $39.2849 \%$ and in house garden about $35.4523 \%$.
\end{abstract}

Key Words: HPLC analysis, Hawthorn, Fatty acids, Triterpenoids, $\omega-3$ fatty acid, $\alpha$-Amyrin, Acetylcholine.

\section{INTRODUCTION}

Hawthorn is a spiking bush or tree, the tree reaches 13 feet in height and grows along the edges of woods and forests. Hawthorn has smooth, gray dark and sharp thorns which grow along the branches. The medicinal parts are the flowers and the fruit (Fig. 1), the Latin name is Crataegus azarolus it belong to the genus (crataegus), the genus (crataegus) is a member of the rose family (Rosaceae). It is cultivated and grows wild in Kurdistan region-north Iraq, a local name of hawthorn fruit in kurdish is (goezh) ${ }^{1}$.

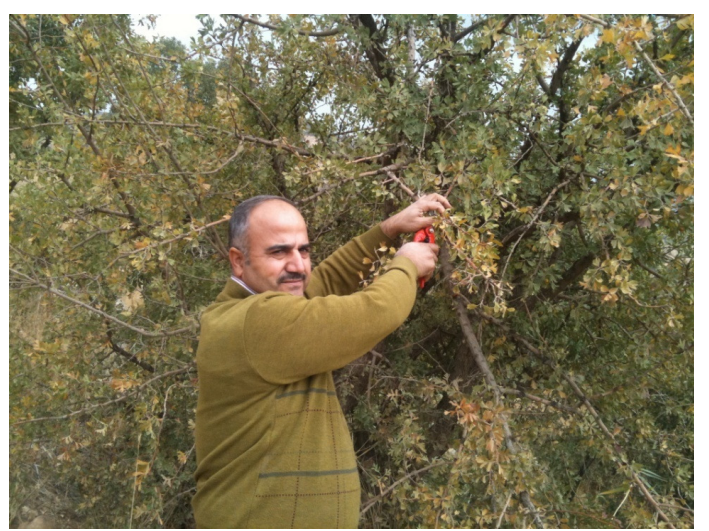

Fig. 1. Dr. Baram while he harvest the hawthorn fruits and its leaves in Qaradax
Hawthorn contains amino acids and essential fatty acids. It also contains the minerals e.g., calcium magnesium, chromium, potassium, selenium, iron and zinc vitamins B-1, B-2, B3 and $\mathrm{C}^{2}$, oleanolic $\operatorname{acid}^{3}$ or oleanic acid (Fig. 2a) is a naturally occurring triterpenoid widely distributed in food and medicinal plants, related to betulinic acid. It is relatively non-toxic, antitumor and hepatoprotective as well as exhibiting antiviral properties ${ }^{4}$, olenalic acid was found to exhibit strong anti HIV activity the related compound betulinic acid was use to create the first commercial maturation inhibitor drug.

An extremely potent synthetic triterpenoid analogue of oleanolic acid was found in 2005. It is a powerful inhibitor of cellular inflammatory processes ${ }^{5}$. Ursolic acid (Fig. 2b) is a pentacyclic triterpene acid, used in cosmetics that is also capable of inhibiting various types of cancer cells by inhibiting the $\mathrm{STAT}_{3}$ activation pathway ${ }^{6,7}$ and human fibrosarcoma cells by reducing the expression of matrix metalloproteinase -9 by acting through the glucocorticoid receptor. It may also decrease proliferation of cancer cells induce apoptosis ${ }^{8}$. Ursolic acid can serve as a starting material for synthesis of more potent bioactive derivatives as antitumor agent ${ }^{9}$ other names for ursolic acid include urson, prunol and malol. $\alpha$ - and $\beta$-amyrin are pentacyclic triterpenes (Fig. 2c,d) found in plants and are known to exhibit pronounced anti-inflammatory effects ${ }^{10}$. Choline is 2-hydroxy-N,N,N-trimethylethanminium (Fig. 3a) the other name of it is bilineurine choline is a water soluble 
<smiles>CC1(C)CCC2(C(=O)O)CC[C@]3(C)C(=CC[C@]4(C)C3CC[C@@H]3C(C)(C)C(O)CCC34C)C2C1</smiles>

(a) Oleanolic acid<smiles>CC1[C@H](C)CCC2(C(=O)O)CC[C@H]3C(=CCC4C3(C)CCC3C(C)(C)C(O)CC[C@@]34C)C12C</smiles>

(b) Ursolic acid

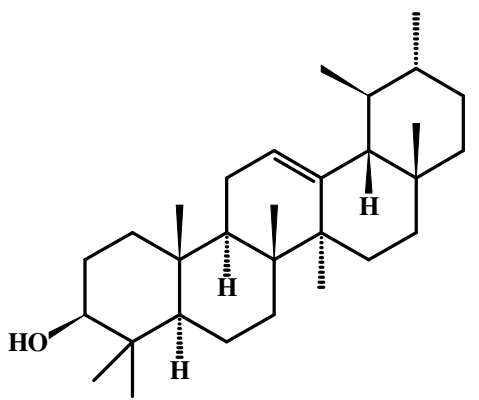

(c) $\alpha$-Amyrin

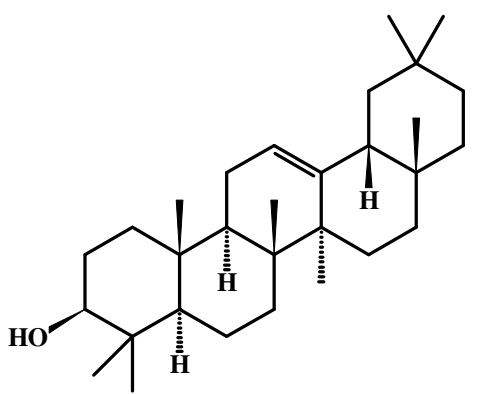

(d) $\beta$-Amyrin

Fig. 2. Chemical structure of hawthorn triterpenoids<smiles>CC(=O)OCC[N+](C)(C)C</smiles>

(a) Acetylcholine<smiles>C[N+](C)(C)CCO</smiles>

(b) Choline
Fig. 3. Chemical structure of acetylcholine and choline

essential nutrient ${ }^{11}$. It is usually grouped within the Bcomplex vitamins, generally refers to the various quaternary ammonium salts and it is a precursor molecule for the neurotransmitter, it must be consumed through the diet in order for the body to remain healthy ${ }^{12}$. Acetylcholine(ash) is 2-acetoxyN,N,N-trimethylethanaminium was first identified in 1914 by
Henry Hall et al., for its action on heart tissue, is one of many neurotransmitters in the autonomic nervous system (ANS) and it slows the heart rate when functioning as an inhibitory neurotransmitters. However it also behaves at neuromuscular junction $^{13}$.

\section{EXPERIMENTAL}

Three types of hawthorn [cartaegus azarolus] fruit, [Hawramane, Qaradax and house garden hawthorn] were harvested in its optimum state for two consecutive seasons in 2011 in Kurdistan region -north Iraq, Hawramane, Qaradax, garden Fig. 1. After a morphological and chemical characterization, the samples were prepared for determination of oils, fatty acids, triterpenoides and other chemical constituents.

A-Preparation of the sample for the determination of total oil contents: The three types of hawthorn fruits Hawramane, Qaradax, house garden were oven-dried at $50^{\circ} \mathrm{C}$ for $18 \mathrm{~h}$ and ground through a wiley mill to pass a 30-40 mesh screen and stored tightly at $4{ }^{\circ} \mathrm{C} .10 \mathrm{~g}$ of the samples were extracted with petroleum ether $\left(40-60{ }^{\circ} \mathrm{C}\right)$ using Soxhlet apparatus according to AAcc methods ${ }^{14}$. The oils were recovered by petroleum ether evaporation in a rotary evaporator at a $60{ }^{\circ} \mathrm{C}$ (Heidolph Laboratory 4003 control). The oils were dried in desiccators for $1 \mathrm{~h}$ and finally the extracted oils were weighted. The percentage of the total oils content are (12, 10 and $14 \%)$, respectively. The characteristic properties of the oil were determined by conventional methods ${ }^{15}$ and the results are presented in Table-1.

\begin{tabular}{lccc}
\multicolumn{4}{c}{ TABLE-1 } \\
\multicolumn{4}{c}{$\begin{array}{c}\text { SPECIFIC TESTS FOR OILS IN HAWTHORN FRUIT } \\
\text { [HAWRAMANE, QARADAX, HOUSE GARDEN] }\end{array}$} \\
\hline \multicolumn{1}{c}{ Samples } & $\begin{array}{c}\text { Hawramane } \\
\text { hawthorn }\end{array}$ & $\begin{array}{c}\text { Qaradax } \\
\text { hawthorn }\end{array}$ & $\begin{array}{c}\text { House garden } \\
\text { hawthorn }\end{array}$ \\
\hline Oil & $12 \%$ & $10 \%$ & $14 \%$ \\
Colour & Light yellow & Light yellow & Light yellow \\
Saponification & 172.10 & 169.00 & 170.10 \\
Iodine value & 152.8 & 152.0 & 150.0 \\
Acid value & 1.25 & 1.20 & 1.21 \\
Peroxide value & 1.20 & 1.19 & 1.21 \\
Ash & $0.2 \mathrm{~g}$ & 0.19 & 0.21 \\
\hline
\end{tabular}

B-Fatty acids composition: Fatty acids were separated on FLC (fast liquid chromatographic) column. Supelcosil LC, $3 \mu \mathrm{m}$ particle size $(50 \mathrm{~mm} \times 4.6 \mathrm{~mm}$ i.d. $)$ column, mobile phase:acetonitrile:acetone $(59: 41, \mathrm{v} / \mathrm{v})$.

Detection: Refractive index detector LC6-RID flow rate $1.0 \mathrm{~mL} / \mathrm{min}$, injection: $20 \mu \mathrm{L}$ saturated and unsaturated fatty acid FAME fatty acid methyl ester. The sequences of the eluted fatty acids standard were as follow, each standard was $50 \mu \mathrm{g} /$ mL C16:1, C18:1, C18:2, C18:3 and C20:2 ${ }^{16}$.

\section{C-Extraction of samples}

By hydro-distillation method: Hydro-distillation extraction method was used for extraction of essential oil, $1 \mathrm{~g}$ of the crushed fruit were immersed, the hot water help to release the aromatic molecules from the fruit, the molecules of these volatile oils evaporate in to steam, the steam, was condense in to liquid form. The oil was separated from water without losing 
oil. The analysis of the oil and its constituents were analysis by HPLC, according to reference analysis procedure ${ }^{17}$.

D-Pentacyclic triterpenoids: The alcoholic extract of pentacyclic triterpenoids were separated on FLC (fast liquid chromatography) column, Um particle size $(50 \mathrm{~mm} \times 4.6 \mathrm{~mm}$ i.d.) chiral column, mobile phase were $0.1 \%$ acetic acid in deionized water:acetonitrile $(20: 80 \mathrm{v} / \mathrm{v})$ detection UV set at $264 \mathrm{~nm}$, flow rate $1.3 \mathrm{~mL} / \mathrm{min}$. The sequence of the eluted standard was $25 \mu \mathrm{g} / \mathrm{mL}$.

$10 \mathrm{~g}$ of each samples were weighed, then dissolved in $10 \mathrm{~mL}$ HPLC methanol, the samples shaking and agitated in ultrasonic bath for $10 \mathrm{~min}$, then concentrated by evaporating the solvent with a stream of liquid $\mathrm{N}_{2}$ until reach $1 \mathrm{~mL}$, then $20 \mu \mathrm{L}$ were injected on HPLC column. The concentration for each compound were quantitatively determined by comparison the peak area of the standard with that of the samples.

Concentration of sample $\mu \mathrm{g} / \mathrm{mL}=$ area of sample/area of standard $\times$ Con. of standard $\times$ dilution factor: The separation occurred on liquid chromatography Shimadzu 10AV-LC equipped with binary delivery pump model LC10AV Shimadzu, the eluted peaks were monitored by UV-VIS 10A-SPD spectrophotometer.

E-Determination of elements: $10 \mathrm{~g}$ of samples were weighted in to a porcelain crucibles, placed in a muffle furnace temperature was increased to $600{ }^{\circ} \mathrm{C}$ and held at the temperature for $6 \mathrm{~h}$, the samples were removed from the furnace and weighted, the determine percentage of ash for samples were $(0.2 \mathrm{~g}),(0.19 \mathrm{~g})$ and $(0.21 \mathrm{~g}) \%$, respectively. The residual ash was dissolved in 1:1 nitric acid filtered and the volume was completed to $(100 \mathrm{~mL})$ distilled water, the solution was injected to OES-ICP Perkin Elmer 2100 for determine.

\section{RESULTS AND DISCUSSION}

Hawthorn fruits [Hawraman, Qaradax and house garden] have oil contents 12,10 and $14 \%$, respectively which have a yellow colour. The characteristics properties of the oils compared well to each other Table-1. The iodine value is often the most useful figure for indentifying oil or at least into a particular group which gives a reasonably quantitative measure for unsaturated of oil ${ }^{18}$. The saponification number represents the amount of saponifiable material which is inversely proportional to the mean of the molecular weights of the fatty acids in the glycerides present ${ }^{18}$. The peroxide value is an indicator of the products of primary oxidation measures rancidity or degree of oxidation but not stability of a fat ${ }^{19}$. A rancid test often begins to be noticeable when the peroxide value is between 10 and $20^{18}$.

The HPLC analysis of fatty acid composition in the three types of hawthorn fruits are presented in Tables 2-4 from the result the each types of hawthorn fruits contain high percentage of $\alpha$-linoleic acid which is the essential fatty acid must

\begin{tabular}{|c|c|c|c|c|c|c|c|c|}
\hline \multicolumn{9}{|c|}{$\begin{array}{l}\text { TABLE-2 } \\
\text { IION IN HAWRAMANE }\end{array}$} \\
\hline No & Subjects & Rt (min) & Area (standard) & $\mathrm{df}$ & Area (sample) & Conc. $(\mu \mathrm{g} / \mathrm{mL})$ & Conc. of sample & $\%$ \\
\hline 1 & Palmatic C16 = 0 & 1.03 & 20765 & 3 & 7108 & 50 & 51.3460 & 7.000621297 \\
\hline 2 & Palmitoleic $\mathrm{C} 16=1$ & 1.87 & 23081 & 3 & 6741 & 50 & 43.8088 & 5.972976517 \\
\hline 3 & Stearic C18 $=0$ & 2.7 & 27714 & 3 & 0 & 50 & 0.0000 & 0 \\
\hline 4 & Oleic C18 = 1 & 3.71 & 24155 & 3 & 20550 & 50 & 127.6133 & 17.399064 \\
\hline 5 & Linoleic C18 = 2 & 4.61 & 18272 & 3 & 8654 & 50 & 71.0431 & 9.686165951 \\
\hline 6 & $\alpha$-Linoleic C18 = 3 & 6.02 & 12482 & 3 & 22706 & 50 & 272.8649 & 37.20296524 \\
\hline \multirow[t]{2}{*}{7} & Arachidic $\mathrm{C} 20=2$ & 6.86 & 17984 & 3 & 19995 & 50 & 166.7732 & 22.738207 \\
\hline & Total & - & - & - & - & - & 733.4494 & - \\
\hline
\end{tabular}

TABLE-3

FATTY ACID COMPOSITION IN QARADAX HAWTHORN FRUIT

\begin{tabular}{|c|c|c|c|c|c|c|c|c|}
\hline No & Subjects & Rt (min) & Area (standard) & df & Area (sample) & Conc. $(\mu \mathrm{g} / \mathrm{mL})$ & Conc. of sample & $\%$ \\
\hline 1 & Palmatic C16 = 0 & 1.03 & 20765 & 3 & 8359 & 50 & 60.3829 & 7.51211981 \\
\hline 2 & Palmitoleic C16 = 1 & 1.87 & 23081 & 3 & 11605 & 50 & 75.4192 & 9.382760694 \\
\hline 3 & Stearic $\mathrm{C} 18=0$ & 2.7 & 27714 & 3 & 10697 & 50 & 57.8967 & 7.202825596 \\
\hline 4 & Oleic C18 = 1 & 3.71 & 24155 & 3 & 0 & 50 & 0.0000 & 0 \\
\hline 5 & Linoleic C18 = 2 & 4.61 & 18272 & 3 & 21107 & 50 & 173.2733 & 21.55661372 \\
\hline 6 & $\alpha$-Linoleic C18 = 3 & 6.02 & 12482 & 3 & 21004 & 50 & 252.4115 & 31.40204614 \\
\hline \multirow[t]{2}{*}{7} & Arachidic C20 $=2$ & 6.86 & 17984 & 3 & 22111 & 50 & 184.4223 & 22.94363403 \\
\hline & Total & - & - & - & - & - & 803.8058 & - \\
\hline
\end{tabular}

TABLE-4

FATTY ACID COMPOSITION IN HOUSE GARDEN HAWTHORN FRUIT

\begin{tabular}{|c|c|c|c|c|c|c|c|c|}
\hline No & Subjects & Rt (min) & Area (standard) & $\mathrm{df}$ & Area (sample) & Conc. $(\mu \mathrm{g} / \mathrm{mL})$ & Conc. of sample & $\%$ \\
\hline 1 & Palmatic $\mathrm{C} 16=0$ & 1.03 & 20765 & 3 & 4490 & 50 & 32.4344 & 4.804159728 \\
\hline 2 & Palmitoleic C16 = 1 & 1.87 & 23081 & 3 & 37429 & 50 & 243.2455 & 36.02936732 \\
\hline 3 & Stearic $\mathrm{C} 18=0$ & 2.7 & 27714 & 3 & 7752 & 50 & 41.9571 & 6.214663013 \\
\hline 4 & Oleic C18 = 1 & 3.71 & 24155 & 3 & 0 & 50 & 0.0000 & 0 \\
\hline 5 & Linoleic C18 = 2 & 4.61 & 18272 & 3 & 15737 & 50 & 129.1895 & 19.13545931 \\
\hline 6 & $\alpha$-linoleic C18 = 3 & 6.02 & 12482 & 3 & 18998 & 50 & 228.3048 & 33.81635063 \\
\hline \multirow[t]{2}{*}{7} & Arachidic $\mathrm{C} 20=2$ & 6.86 & 17984 & 3 & 0 & 50 & 0.0000 & 0 \\
\hline & Total & - & - & - & - & - & 675.1313 & - \\
\hline
\end{tabular}


TRITERPENOIDS COMPOSITION IN HAWRAMANE HAWTHORN AND OTHER CHEMICAL CONSTITUENT*

\begin{tabular}{clccccccc}
\hline No & \multicolumn{1}{c}{ Subjects } & Rt $(\mathrm{min})$ & Area (standard) & $\mathrm{df}$ & Area (sample) & Conc. $(\mu \mathrm{g} / \mathrm{mL})$ & Conc. of sample & $\%$ \\
\hline 1 & Chlorogenic acid & 0.89 & 21630 & 3 & 0 & 25 & 0.0000 & 0 \\
2 & Oleanolic acid & 2.03 & 20404 & 3 & 17070 & 25 & 62.7450 & 2.772614876 \\
3 & Ursolic acid & 2.87 & 22267 & 3 & 13878 & 25 & 46.7441 & 2.065553827 \\
4 & Q-Amyrin & 3.87 & 13168 & 3 & 27898 & 25 & 158.8966 & 7.021414227 \\
5 & $\beta$-Amyrin & 4.94 & 16621 & 3 & 85319 & 25 & 384.9904 & 17.01217924 \\
6 & *Choline & 5.87 & 20287 & 3 & 106067 & 25 & 392.1243 & 17.32741588 \\
7 & *Acetylcoline & 6.77 & 31108 & 3 & 504998 & 25 & 1217.5276 & 53.80082195 \\
& Total & - & - & - & - & - & 2263.0280 & - \\
\hline
\end{tabular}

TABLE-6

TRITERPENOIDS COMPOSITION IN QARADAX HAWTHORN AND OTHER CHEMICAL CONSTITUENT*

\begin{tabular}{clccccccc}
\hline No & \multicolumn{1}{c}{ Subjects } & Rt $(\mathrm{min})$ & Area (standard) & $\mathrm{df}$ & Area $($ sample) & Conc. $(\mu \mathrm{g} / \mathrm{mL})$ & Conc. of sample & $\%$ \\
\hline 1 & Chlorogenic acid & 0.89 & 21630 & 3 & 0 & 25 & 0.0000 & 0 \\
2 & Oleanolic acid & 2.03 & 20404 & 3 & 28840 & 25 & 106.0086 & 3.582365987 \\
3 & Ursolic acid & 2.87 & 22267 & 3 & 22177 & 25 & 74.6969 & 2.524242642 \\
4 & $\alpha$-Amyrin & 3.87 & 13168 & 3 & 69842 & 25 & 397.7939 & 13.44271097 \\
5 & $\beta$-Amyrin & 4.94 & 16621 & 3 & 108542 & 25 & 489.7810 & 16.55124555 \\
6 & *Choline & 5.87 & 20287 & 3 & 314452 & 25 & 1162.5129 & 39.28498067 \\
7 & *Acetylcoline & 6.77 & 31108 & 3 & 302115 & 25 & 728.3858 & 24.61445418 \\
& Total & - & - & - & - & - & 2959.1791 & - \\
\hline
\end{tabular}

TABLE-7

TRITERPENOIDS COMPOSITION IN HOUSE GARDEN HAWTHORN AND OTHER CHEMICAL CONSTITUENT*

\begin{tabular}{|c|c|c|c|c|c|c|c|c|}
\hline No & Subjects & Rt (min) & Area (standard) & df & Area (sample) & Conc. $(\mu \mathrm{g} / \mathrm{mL})$ & Conc. of sample & $\%$ \\
\hline 1 & Chlorogenic acid & 0.89 & 21630 & 3 & 0 & 25 & 0.0000 & 0 \\
\hline 2 & Oleanolic acid & 2.03 & 20404 & 3 & 17579 & 25 & 64.6160 & 4.611192631 \\
\hline 3 & Ursolic acid & 2.87 & 22267 & 3 & 17733 & 25 & 59.7285 & 4.262407024 \\
\hline 4 & $\alpha$-Amyrin & 3.87 & 13168 & 3 & 21322 & 25 & 121.4421 & 8.666475927 \\
\hline 5 & $\beta$-Amyrin & 4.94 & 16621 & 3 & 50270 & 25 & 226.8365 & 16.18773736 \\
\hline 6 & $*$ Choline & 5.87 & 20287 & 3 & 134378 & 25 & 496.7886 & 35.45232792 \\
\hline \multirow[t]{2}{*}{7} & *Acetylcoline & 6.77 & 31108 & 3 & 179130 & 25 & 431.8744 & 30.81985914 \\
\hline & Total & - & - & - & - & - & 1401.2862 & - \\
\hline
\end{tabular}

be taking from diet because the human body not able to synthesized it. Hawraman hawthorn does not contain stearic acid, while Qaradax hawthorn does not contain oleic acid and house garden hawthorn does not contain oleic acid and arachidic acid but contain high percentage of palmitoleic acid ca. $36.029 \%$.

HPLC analysis of triterpenoids compounds in hawthorn samples are presented in Tables 5-7. All the four different triterpenoids compound are indicated in all three samples of hawthorn oleanolic acid, ursolic acid, $\alpha$-amyrin and $\beta$-amyrin (Fig. 2), all samples contain high percentage of $\beta$-amyrin while Qaradax hawthorn contain high percentage of $\alpha$-amyrin $(13.442 \%)$ by comparison with Hawraman and house garden hawthorn (7.021 and $8.664 \%)$. Another natural occurring compounds like choline and acetylcholine are detected in these hawthorn fruits as shown in Fig. 3, Qaradax and house garden hawthorn contain high percentage of choline 39.284 and $35.452 \%$, while Hawraman hawthorn fruit contain high percentage of acetylcholine ca. $53.800 \%$.

Elemental analysis have been done by Inductive couple plasma [ICP] techniques (OES-ICP Perkin Elmer 2100) for each types of hawthorn and the result cited in Table- 8 which a high amount of $\mathrm{Cu}$ and Mo elements have been detected in each of these three types of hawthorn fruits [in ppb].

\begin{tabular}{cccc}
\hline \multicolumn{5}{c}{ TABLE-8 } \\
\multicolumn{4}{c}{ ELEMENTAL ANALYSIS OF HAWTHORN FRUITS } \\
[HAWRAMANE, QARADAX, HOUSE GARDEN, ppb]
\end{tabular}

\section{Conclusion}

The three types of hawthorn fruits [Hawraman, Qaradax and house garden] in Iraqi Kurdistan region are rich source of polyunsaturated fats including $\alpha$-linoleic acid (according to HPLC analysis) and triterpenoids compound including $\beta$-amyrin which is knowing as exhibit pronounced anti-inflammatory effect, also all three types of hawthorn fruit contain another phytochemical compounds like choline and acetylcholine which they have special physiological effect in our body especially action of neurotransmitter and the amount of these elements like $\mathrm{Co}, \mathrm{Cr}, \mathrm{Cu}, \mathrm{Mo}, \mathrm{Ni}$ and $\mathrm{Se}$ are exist in these fruits, for that we must consume it through our diet in order to the remain healthy. 


\section{ACKNOWLEDGEMENTS}

The authors are very much indebted to the Department of Chemistry, School of Science Faculty of Science, University of Sulaimani for providing the facilities, encouragement and financial support during the investigation. Thanks are also due to University of Baghdad for providing HPLC techniques for identification of the chemical components in all hawthorn fruits.

\section{REFERENCES}

1. H.I. Chakravary and Ali-Al-Rawi, Medicinal Plant of Iraq, Ministry of Agriculture Baghdad, edn. 2, 1 (1964).

2. Prescription for Nutritional Healing Phylis Balch, University of Maryland Medical Center-Hawthorn (2003).

3. T. Cui, J.-Z. Li, H. Kayahara, L. Ma, L.-X. Wu and K. Nakamura, J. Agric. Food Chem., 54, 4574 (2006).

4. J. Liu, J. Ethnopharmacol., 49, 57 (1995).

5. A.T. Dinkova-Kostova, K.T. Liby, K.K. Stephenson, W.D. Holtzclaw, X. Gao, N. Suh, C. Williams, R. Risingsong, T. Honda, G.W. Gribble, M.B. Sporn and P. Talalay, Proc. Nat. Acad. Sci. USA, 102, 4584 (2005).

6. S. Shishodia, S. Majumdar, S. Banerjee and B.B. Aggarwal, Cancer Res., 63, 4375 (2003).

7. A.K. Pathak, M. Bhutani, A.S. Nair, K.S. Ahn, A. Chakraborty, H. Kadara, S. Guha, G. Sethi and B.B. Aggarwal, Mol. Cancer Res., 5, 943 (2007).
8. X. Wang, F. Zhang, L. Yang, Y. Mei and H. Long, J. Biomed. Biotechnol., 2011, 419343 (2011)

9. M. Mac, S.Q. Cai, J.R. Cui and R.Q. Wang, Eur. J. Med. Chem., 40, 582 (2005).

10. C.E. Vitor, C.P. Figueiredo, D.B. Hara, A.F. Bento, T.L. Mazzuco and J.B. Calixto, Br. J. Pharmacol., 157, 1034 (2009).

11. Dietary Reference Intakes for Thiamine, Riboflavin, Niacin, Vitamin B6, Folate, Vitamin B12, Panthothenic Acid, Biotin and Chloine, Institute of Medicine (1998).

12. http/Ipi oregonstate edu /infocenter /othernvts/choline (at Linus paulin lnst )AJCN 92 n5 1113-1119(Nov2010)

13. N.A. Compbell and J.B. Reece, 48 Biology, SanFrancisco, CA, Pearson Education, Inc., edn. 6, p. 1037 (2002).

14. AAcc, Approved Methods of the AAcc, American Association of Coreal Chemists INC, stpau, Minn (1987).

15. J.Y. Goe, J. Am. Oil Chem. Soc., 72, 120 (1995).

16. ISO/IEC 17025: 1999. The Present List of Methods Reflects the Amendments Adopted by the 34th Session of the Codex Alimentarius Commission in (2011)

17. www.che.utah.edu/.../Instrumental\%20Analysis\%20CHE5503/.../ HPLC\%20Procedure\%20Final

18. D. Pearson, The Chemical Analysis of Food, Chemical Publishing Company INC. New York, edn. 6 (1971).

19. D.T. Plummer, An Introduction to Practical Biochemistry, Academic Press, London, edn. 3 (1987). 